\title{
Implementasi Metode Al Miftah Lil Ulum Dalam Membaca Kitab Fathul Qorib Bagi Pemula Di Pondok Pesantren Sidogiri Salafi Kabupaten Pasuruan
}

\author{
Maulana Restu, ${ }^{1}$ Siti Wahyuni² \\ 1 Pascasarjana Institut Agama Islam Tribakti Kediri, Institut Agama Islam Tribakti Kediri \\ ${ }^{1}$ sitimuarrifah1234@gmail.com, 2yunilirboyo@gmail.com
}

\begin{abstract}
Islamic education in Indonesia, the majority is rooted in the education model of an Islamic boarding school. In the world of pesantren, the position of the yellow book is very strategic because the yellow book is the book references and the curriculum in the education system. Nahwu and Shorrof are the initial keys to mastering the yellow book, but the problem is, many students, especially early childhood students and beginners, they find it difficult to learn Nahwu and Shorof, while the two fans are the key to being able to read the yellow book. with 3 (three) data collection techniques, namely; observation, interview and documentation. The analysis technique in this research is to use qualitative data analysis consisting of 1) data reduction; 2) data presentation, and 3) conclusions, where the process took place circularly during the study. The results showed that the preparation of the method was based on the unrest that occurred in the Sidogiri Islamic Boarding School and the Al-Miftah Lil ‘Ulum method in the Sidogiri Islamic Boarding School well organized, both internally and externally.
\end{abstract}

Keywords: Enrichment of Learning, Human Reproduction, Islamic Views

\begin{abstract}
Abstrak
Pendidikan Islam di Indonesia, mayoritas berakar dari pendidikan model pondok pesantren. Dalam dunia pesantren, posisi kitab kuning sangat strategis karena kitab kuning dijadikaan the book references, dan kurikulum dalam sistem pendidikannya. Nahwu dan shorrof merupakan kunci awal untuk menguasai kitab kuning, namun permasalahannya, banyak santri, utamanya santri usia dini dan pemula, mereka merasa kesulitan untuk mempelajari Nahwu dan Shorof, sedangkan kedua fan tersebut merupakan kunci untuk bisa membaca kitab kuning. dengan 3 (tiga) teknik pengumpulan data, yaitu; observasi, wawancara dan dokumentasi. Adapun teknik analisis dalam penelitian ini yaitu dengan menggunakan analisis data kualitatif yang terdiri dari: 1) reduksi data; 2) penyajian data; dan 3) kesimpulan, dimana prosesnya berlangsung secara sirkuler selama penelitian berlangsung. Hasilnya menunjukkan bahwa penyusunan metode dilatarbelakangi keresahan-keresahan yang terjadi di Pesantren Sidogiri dan metode Al-Miftah Lil 'Ulum di Pesantren Sidogiri di organisir dengan baik, baik di secara internal maupun eksternal.
\end{abstract}

Kata Kunci: Pengayaan Pembelajaran, Reproduksi Manusia, Pandangan Islam 


\section{Pendahuluan}

Pendidikan Islam di Indonesia, mayoritas berakar dari pendidikan model pondok pesantren, baik yang sudah di desain dengan bentuk pendidikan formal, maupun yang masih berbentuk non formal. ${ }^{1}$ Alasan pokok munculnya pesantren ini adalah untuk mentransmisikan Islam tradisional sebagaimana yang terdapat dalam kitab-kitab klasik yang ditulis berabad-abad yang lalu. Kitab-kitab ini dikenal di Indonesia sebagai kitab kuning. ${ }^{2}$

Adapun pengertian umum yang beredar dikalangan pemerhati pesantren, kitab kuning adalah kitab-kitab keagamaan berbahasaa Arab atau berhuruf Arab, sebagai produk pemikiran ulama masa lampau yang ditulis dengan format khas pra-modern, sebelum abad ke-17-an M. ${ }^{3}$ ada juga yang mengartikan kitab kuning juga kerap disebut kitab gundul karena memang tidak memiliki harakat atau syakl, seperti fathah, kasrah, dhammah dan sukun. Juga, karena tidak ada torehan arti (makna) di bawah setiap lafalnya.

Pesantren dan kitab kuning merupakan dua sisi yang tidak terpisahakan dalam keping pendidikan

${ }^{1}$ M. Ahsanul Husna, "Metode Diskusi Dalam Pemebelajaran Kitab Kuning Klasik Dalam Peningkatan Keterampilan Membaca", Universitas Wahid Hasyim, 2 (2019), h 115.

2 Martin van bruinessen, Kitab Kuning Pesantren dan Tarekat (Yogyakarta : Gading publishing, 2015), h. 85.

${ }^{3}$ H. Affandi Mochtar, Kitab Kuning dan Tradisi Akademik Pesantren (Bekasi; Pustaka Isfahan, 2010). h. 32. agama Islam di Indonesia. Sejak sejarah awal berdirinya, pesantren tidak dapat dipisahkan dari literatur kitab buah pemikiran dan karya tulis para ulama klasik yang tidak ragu lagi kreadibilitasnya. ${ }^{4}$ Komponen di dalamnya adalah seorang kyai yang kharismatik dan ditaati menjadi tokoh sentral, ratusan hingga ribuan santri yang mengaji, sang kyai membaca kitab kuning sambil menanamkan jati diri dan membuka kesadaran para santri akan pentingnya keimanan, kemanusian dan kemandirian melalui kitab kuning. ${ }^{5}$

Jumlah penulisan kitab dalam bahasa Arab inilah yang menjadi ciri penting, dan sekarang terdapat di pasaran lebih dari 500 judul karya ulama tradisional indonesia, yang isinya beraneka ragam, dari terjemahan karya sederhana sampai syarah dan hasyiyah canggih terhadap teks klasik. ${ }^{6}$

Dalam dunia pesantren, posisi kitab kuning sangat strategis karena kitab kuning dijadikaan thex book references dan kurikulum dalam sistem pendidikan pesantren. Selain sebagai pedoman bagi tata cara keberagamaan, kitab kuning juga difusingkan oleh kalangan pesantren

\footnotetext{
4 Syarif, "Tradisi Dan Kontektualisasi Kitab Kuning di Pesantren: Studi Kasus di Pondok Pesantren Miftahul Huda Manonjaya Tasikmalaya", Balaia Penelitian Agamaa Jakartaa (2014), h. 3.

${ }_{5}$ M. Masyhuri Mochtar, Dinamika Kajian Kitab Kuning di Pesantren (Pasuruan: Pustaka Sidogiri, 1436 H), h. 15.

${ }^{6}$ Van Bruinessen, h. 88.
} 
sebagai referensi universal dalam menyikapi segala tantangan kehidupan. ${ }^{7}$

Nahwu dan Shorrof merupakan kunci awal untuk menguasai kitab kuning, bahkan ada yang mengatakan bahwa Nahwu adalah ibunya dan Shorrof adalah bapaknya. ${ }^{8}$ di dalam kurikulum pondok pesantren, tingkatan belajar Nahwu dimulai dari kitab AlAjurumiyyah, Kemudian nadhom AlImrithiy, dan tingkat yang tertinggi AlFiyyah Ibni Malik. Hal ini menuntut waktu yang relatif lama, sedangkan saat ini, seiring dengan perkembangan zaman dan teknologi, perjalanan waktu terasa sangat singkat, dan harus diimbangi dengan percepatan dibidang pendidikan dalam bentuk formulasi baru, berupa metode atau sistem pengajaran yang mampu memperpendek masa belajar ilmu Nahwu dan Shorrof yang menjadi kunci belajar kitab kuning.

Disamping itu, banyak santri, utamanya santri usia dini dan pemula, mereka merasa kesulitan untuk mempelajari Nahwu dan Shorrof, sehingga menyebabkan para santri usia dini dan santri pemula tidak aktif mengikuti pelajaran dan cenderung malas-malasan, karena sulit memahami pelajaran Nahwu dan Shorrof tersebut, sedangkan kedua fan tersebut merupakan kunci untuk bisa membaca kitab kuning.

Fenomena diatas menuntut para pengelola pendidikan atau pengurus pesantren untuk mencari formulasi baru yang cocok dengan santri usia dini dan para pemula agar cepat bisa membaca kitab kuning. Salah satu solusi yang ditempuh oleh mayoritas pengelola (kyai) pondok pesantren adalah dengan mengadopsi metode khusus percepatan membaca kitab kuning bagi santri usia dini dan para pemula. Adapun metode yang digunakan antara lain adalah metode al-Miftah lil-‘Ulum, Amtsilati, Tamyiz dan Nubdzatul Bayan. Akan tetapi penulis memfokuskan kepada metode al-Miftah lil-`Ulum.

Selain itu, berdasarkan fakta yang penulis alami mulai sejak menempuh sekolah dasar sampai dengan perguruan tinggi, penulis tidak pernah menemukan metode praktis dalam mempermudah membaca kitab kuning ini, sekalipun di pesantren penulis sekarang (ponpes Lirboyo Kediri).

Dengan latar belakang tersebut, penulis ingin menggali lebih dalam lagi mengenai membaca kitab kuning dalam dinamika santri di lingkungan Pesantren dengan metode al-Miftah lil-‘Ulum yang dituangkan dalam judul tesis "Implementasi metode al-Miftah lil 'Ulum dalam membaca Fathul Qorib (kitab kuning) bagi pemula di Pondok Pesantren Sidogiri Salafi Kabupaten Pasuruan".

Dan karena metode al-Miftah lil 'Ulum ini dirintis di Pesantren Sidogiri Kabupaten Pasuruan, maka penulis memilih lokasi penelitian di tempat

8 Syaifuddin Masykuri, Kajian dan Analisis Alfiyyah (Kediri: Santri Salaf Press, 2016), h. 1.
${ }^{7}$ Abdullah Aly, Pendidikan Islam Multikultural di Pesantren (Yogyakarta, Pustaka Pelajar, 2011), h. 185. 
tersebut agar bisa langsung ber-tabarruk kepada para penerus dan kepada lembaga pencipta metode al-Miftah lil'Ulum dan memperoleh data yang valid dari sumbernya.

\section{Metode}

Pendekatan penelitian yang digunakan adalah pendekatan metodologi kualitatif. Menurut Bogdan dan Taylor mendefinisikan metodologi kualitatif sebagai prosedur penelitian yang menghasilkan data deskriptif berupa kata-kata tertulis atau lisan dari orang-orang dan perilaku yang dapat diamati. ${ }^{9}$ Sedangkan jenis penelitiannya adalah menggunakan studi kasus. Studi kasus adalah penelitian yang pada umumnya bertujuan untuk mempelajari secara mendalam terhadap suatu individu, kelompok, lembaga, atau masyarakat tertentu, tentang latar belakang, keadaan sekarang, atau interaksi yang terjadi. ${ }^{10}$

Jadi, karena dalam penelitian ini menyangkut tentang metode Al-Miftah Lil Ulum dalam membaca kitab kuning bagi pemula, yang dirancang dengan menggunakan studi kasus, maka peneliti berusaha melihat secara mendalam permasalahan tersebut di Pondok pesantren Sidogiri Kabupaten Pasuruan.

${ }^{9}$ Lexy J. Moeloeng, Metodologi Penelitian Kualitatif edisi revisi, (Bandung: PT. Remaja Rosdakarya, 2012), h. 4.

10 Gempur Santoso, Fundamental Metodologi Penelitian Kuantitatif dan Kualitatif (Jakarta: Prestasi Pustaka, 2005), hal. 30.

\section{Hasil dan Pembahasan}

Prencanaan Penyusunan Metode AlMiftah Lil ‘Ulum

Faktor utama yang melatar belakangi lahirnya metode Al-Miftah Lil 'Ulum adalah hasil belajar baca kitab santri di pondok Sidogiri yang begitu menurun, serta target-target pendidikan membaca kitab yang tidak tercapai. ${ }^{11}$ Hasil belajar adalah kompetensi atau kemampuan tertentu baik kognitiff, afektif maupun psikomotorik yang dicapai atau dikuasai peserta didik setelah mengikuti proses belajar mengajar. ${ }^{12}$ Hasil belajar yang dicapai peserta didik sangat erat kaitannya dengan rumusan tujuan intruksional yang direncanakan guru sebagai perancang belajar mengajar. Tujuan intruksional pada umumnya dikelompokkan ke dalam kategori domain kognitif, afektif dan psikomotorik. ${ }^{13}$ Dengan hadirnya Al-Miftah sebagai metode pembelajaran di Sidogiri maka Sidogiri lebih dikenal dengan metode pembelajarannya. ${ }^{14}$ Metode pembelajaran sendiri dapat diartikan sebagai cara yang dipergunakan oleh pendidik dalam mengadakan hubungan dengan peserta didik pada saat berlangsungnya proses pembelajaran. Dengan demikian, metode pembelajaran merupakan alat untuk

${ }^{11}$ Muhairil Yusuf, wawancara, Tim Marketing Tim Al-Miftah Luar PPS Sidogiri Pasuruan, 09 Juli 2019

12 Kunndar, Penilaian Autentik, (Jakarta: PT Raja Grafindo Persada, 2013), h. 62

13 Uzer Usman, Menjadi Guru Profesional, (Bandung: Remaja Rosada Karya, 2009), h. 34

${ }_{14}$ Muhairil Yusuf, wawancara, Tim Marketing ..........09 Juli 2019 
menciptakan proses pembelajaran yang diharapkan. ${ }^{15}$

Para pengamat dan pengelola pendidikan pondok Sidogiri yakni Badan Tarbiyah wa Ta'lim Madrosy (BATARTAMA) merumuskan langkahlangkah dengan menyusunnya secara sistematis agar hasil dan tujuan dari metode yang dirumuskan dapat dicapai sesuai target. Sedangkan langkahlangkah penyusunan metode Al-Miftah Lil 'Ulum akan dijelaskan sebagai berikut:

1) Merumuskan Tujuan Pembelajaran

Tujuan pembelajaran merupakan komponen utama yang harus dirumuskan oleh guru dalam pembelajaran, karena merupakan sasaran dari proses pembelajaran. Mau di bawa kemana siswa, apa yang harus dimiliki oleh siswa, semuanya tergantung pada tujuan yang ingin dicapai. Oleh karenanya, tujuan pembelajaran merupakan komponen pertama dan utama. ${ }^{16}$ Adapun tujuan di susunnya metode Al-Miftah Lil 'Ulum ini yaitu anak sudah bisa baca kitabnya sendiri ketika belajar di tingkat ibtidaiyah, ketika masa belajar di tingkat Tsanawiyah sudah bisa baca kitab lain yang tidak dipelajari tanpa ada maknanya, dan ketika belajar aliyah tentunya sudah pengembangan kalau perlu sudah bisa ngarang kitab.

15 Ramayulis, Metodologi Pendidikan Agama Islam, (Jakarta: Kalam Mulia, 2010), h. 3

16 Wina Sanjaya, Strategi Pembelajaran Berorientasi Standar Proses Pendidikan (Jakarta: Kencana, 2008), h. 59
2) Menentukan Materi Pelajaran

Materi pelajaran dapat dibedakan menjadi: pengetahuan (knowledge), ketrampilan (skill), dan sikap (attitude). Pengetahuan menunjuk pada informasi yang disimpan dalam pikiran (mind) murid, ketrampilan menunjuk pada pada tindakan-tindakan (fisik dan non fisik), sikap menunjuk pada kecenderungan seseorang untuk bertindak sesuai dengan nilai dan norma yang diyakini kebenaranya oleh murid. ${ }^{17}$ Dalam pembelajaran konvesional, sering guru menentukan buku teks sebagai satusatunya sumber materi pelajaran. Bahkan, pembelajaran yang berorientasi kepada kurikulum subjek akademis, buku teks yang telah disusun oleh para pengembang kurikulum merupakan sumber utama. ${ }^{18}$

Materi yang digunakan untuk pembelajaran kitab kuning di pesantren Sidogiri bersumber dari kitab Jurmiyah dan ditambah dengan nazham Imrithi dan Al-fiyah, kemudian dikumpulkan menjadi empat jilid, dan di setiap jilid terdapat target-target yang harus dicapai sebagaimana yang akan dijelaskan di bawah ini: 19

\section{1) Jilid pertama}

Dalam jilid pertama santri-santri ditargetkan paham tentang kalimat isim

${ }_{17}$ Wina Sanjaya, Perencanaan dan Desain Sistem Pembelajaran, (Jakarta: Kencana Prenada Media Group, 2012), h.,141-142.

18 Wina Sanjaya, Perencanaan dan Desain Sistem Pembelajaran,.... h.,146

${ }^{19}$ Muhairil Yusuf, wawancara, Tim Marketing .. 09 Juli 2019 
fi'il dan huruf sedangkan indikatornya adalah santri bisa membedakan kalimat isim, fi'il dan huruf. Dan bisa membedakan Isim Mabni dan Mu'rob.

2) Jilid kedua.

Dalam jilid dua santri-santri ditargetkan paham terhadap isim nakirah dan ma'rifat beserta pembagiannya, sedangkan indikatornya adalah santrisantri mampu menentukan isim nakirah dan ma'rifat muzhakkar dan muannas jamid dan mustaq.

3) Jilid ketiga

Dalam jilid ketiga target pencapaiannya adalah santri-santri paham tentang fi'il yang babni, mu'rab mujarrad, mazid lazim mutaaddi ma'lum majhul dan shohih mu'tal sedangkan indikatornya adalah santri-santri mampu membedakan antara mabni dan murab mujarrad dan mazid lazim dan mutaaddi ma'lum dan majhul dan shohih dan mu'tal.

3) Jilid keempat

Pada Jilid Keempat santri-santri ditargetkan harus paham tentang isimisim yang harus dibaca rofa' isim-isim yang dibaca nashob dan isim-isim yang dibaca jer. Sedangkan indikatornya adalah santri-santri mampu menentukan mana isim yang harus dibaca rofa', nashob dan jer.

4) Menentukan Metode Pembelajaran

Metode mengajar adalah alat yang merupakan bagian dari perangkat dan cara dalam pelaksanaan suatu strategi

${ }^{20} \mathrm{JJ}$. Hasibuan dan Moedjiono, Proses Belajar Mengajar, (Bandung: PT. Remaja Rosdakarya, belajar mengajar. ${ }^{20}$ Sedangkan Nana Sudjana mengemukakan, metode pembelajaran sebagai cara yang digunakan guru dalam mengadakan hubungan dengan siswa pada saat berlangsungnya pengajaran. ${ }^{21}$ Jadi, metode pembelajaran dapat diartikan sebagai cara yang digunakan untuk mengimplementasikan rencana yang sudah disusun dalam bentuk kegiatan nyata dan praktis untuk mencapai tujuan pembelajaran. Dalam praktik pembelajaran, terdapat beragam jenis dan metode pembelajaran dan penerapannya. Peneliti mencatat, setidaknya terdapat sebelas metode pembelajaran yang dapat digunakan dalam pelaksanaan pembelajaran. Kesebelas metode tersebut adalah sebagai berikut: 22

a) Metode Proyek, yaitu metode yang bertitik tolak dari suatu masalah, kemudian dibahas dari berbagai segi yang berhuungan sehingga pemecahannya secara komprehensif dan bermakna.

b) Metode eksperimen, yaitu metode yang mengedepankan aktivitas percobaan, sehingga siswa mengalami dan membuktikan sendiri sesuatu yang dipelajari.

c) Metode tugas/resitasi, yaitu guru memberikan tugas tertentu agar siswa melakukan kegiatan belajar.

d) Metode diskusi, yaitu siswa dihadapkan pada suatu masalah yang

${ }^{21}$ Nana Sudjana, Dasar-Dasar Proses Belajar Mengajar, (Bandung: Sinar Baru Algensindo, 2009), h. 76.

${ }^{22}$ Fattah Syukur, Metodik Khusus Pendidikan Agama Islam, (Semarang: AKFI Media, 2009), h. 40 
biasa berupa pernyataan atau pernyataan yang bersifat problematis untuk dibahas dan dipecahkan secara bersama.

e) Metode sosiodrama, yaitu siswa mendramatisasikan tingkah laku dalam hubungannya dengan masalah.

Dari beberapa penjelasan tentang jenis-jenis metode pembelajaran di atas, maka dapat dikemukakan bahwa betapa banyak metode pembelajaran yang bias digunakan oleh seorang guru atau tenaga pengajar dalam melaksanakan proses belajar mengajar. Oleh karena itu, dalam penerapanya diperlukan kreativitas dan variasi untuk menggunakan metodemetode pembelajaran tersebut. ${ }^{23}$

Metode yang akan disusun dan digunakan pesantren Sidogiri dalam pembelajaran kitab kuning tidak hanya menggunakan metode klasik seperti Sorogan dan bandongan namun juga menggunakan metode pembelajaran yang mampu membuat siswa aktif, kreatif, dan menyenangkan sehingga dengan demikian di akhir proses pembelajaran santri-santri dapat menguasai materi pelajaran dengan baik.

5) Mengadakan Placement Test

Tes ini berfungsi untuk mengetahui kemampuan siswa sehingga nantinya pengurus bisa menentukan pada jilid berapa dia harus belajar. Sedangkan prosedur tesnya adalah pertama santri datang ke pondok dan mendaftarkan diri

${ }^{23}$ Eveline Siregar dan Hartini Nara, Teori Belajar dan Pembelajaran, (Bogor: Ghalia Indonesia, 2010), hlm 80-81. dengan mengisi formulir pendaftaran tujuannya adalah untuk mengetahui biodata santri, kemudian setelah itu santri datang ke madrasah i'dadiyah menunjukkan formulir pendaftaran sebagai tanda mereka sudah daftar mondok di pondok pesantren Sidogiri kemudian menunggu waktu kapan harus tes masuk. ${ }^{24}$

6) Menentukan Media Pembelajaran

Kata media berasal dari bahasa Latin yang merupakan bentuk jamak dari kata medium yang secara harfiah dapat diartikan sebagai perantara atau pengantar. Media pengajaran meliputi perangkat keras (hardware) dan perangkat lunak (software). Hardware adalah alat-alat yang dapat mengantar pesan seperti Over Head Projector, radio, televisi, dan sebagainya. Sedangkan Software adalah isi program yang mengandung pesan seperti informasi yang terdapat pada transparansi atau buku dan bahan-bahan cetakan lainnya, cerita yang terkandung dalam film atau materi yang disuguhkan dalam bentuk bagan, grafik, diagram, dan lain sebagainya. ${ }^{25}$

Berdasarkan pengamatan peneliti ketika mengikuti proses pembelajaran di pondok pesantren Sidogiri media yang digunakan dalam proses pembelajaran diantaranya; buku ajar, papan tulis, spidol, alas duduk dan benner-benner yang memuat contoh-contoh kalimat. Namun, walaupun hanya dengan media

24 Observasi pada tanggal · 9 Juli 2019 di depan Gedung Sekretariat PP Sidogiri

25 Wina Sanjaya, Perencanaan dan Desai Sistem....hlm.,204-105 
yang seperti itu, tercifta suasana belajar yang menarik dan kualitas membaca kitab kuning tiap tahun terus mengalami peningkatan yang sangat signifikan.

\section{Pelaksanaan pembelajaran metode Al-} Miftah Lil ‘Ulum

Prosedur pembelajaran kitab kuning dengan metode Al-Miftah Lil 'Ulum terbagi menjadi tiga bagian yaitu; kegiatan pendahuluan, kegiatan inti pembelajaran, dan kegiatan penutup. Ketiga kegiatan tersebut tersusun menjadi satu dalam satu kegiatan pembelajaran dan tidak dapat dipisahpisahkan dengan kegiatan yang lainnya.

\section{Kegiatan Pendahuluan}

Pendahuluan merupakan kegiatan awal dalam suatu pertemuan pembelajaran yang ditujukan untuk membangkitkan motivasi dan memfokuskan perhatian peserta didik untuk berpartisipasi aktif dalam proses pembelajaran. Sedangkan kegiatan yang dilakukan guru dan murid pada kegiatan pendahuluan dalam proses pembelajaran kitab kuning dengan menggunakan materi Al-Miftah Lil 'Ulum di pondok pesantren Sidogiri adalah sebagai berikut: 26

1) Membaca nazhaman

2) Berdo'a

3) Guru atau ustad mengecek kehadiran peserta didik

4) Guru atau ustad menyuruh peserta didik mengisi tempat yang kosong di depan.

${ }^{26}$ Ustadz Syah Jalal, wawancara, Wakil II Madrasah di PP Sidogiri Pasuruan, 09 Juli 2019.
5) Kemudian guru menjelaskan secara singkat materi yang sudah dipelajari sebelumnya kemudian dikaitkan dengan materi yang akan dipelajari sekarang.

\section{Kegiatan Inti}

Kegiatan inti merupakan proses pembelajaran untuk mencapai kemampuan yang diinginkan. Oleh karena itu, dalam proses pembelajaran kitab kuning guru di tuntut untuk melakukan beberapa kegiatan. Kegiatan yang dilakukan guru dalam proses pembelajaran kitab kuning di pondok pesantren Sidogiri akan dijelaskan sebagai berikut:

1. Menjelaskan Materi Pelajaran

2. Memberi Kesempatan Peserta didik Untuk Bertanya. ${ }^{27}$

3. Membuat Kelompok Belajar.

3. Kegiatan Penutup

Tahap penutup pembelajaran kitab kuning di pesantren Sidogiri adalah sebagai berikut:

1) Guru menyimpulkan materi

2) Guru motivasi peserta didik untuk selalu menyempatkan diri membaca kitab kuning walau hanya lima baris

3) Membaca doa bersama.

\section{Evaluasi pembelajaran metode Al- Miftah Lil 'Ulum}

Menurut Grounlund, pengertian evaluasi adalah "evaluation is a sistem atic process of determining the extent to wich instructional objectives are achieved by pupil". Di sisi lain, sedangkan

${ }^{27}$ Observasi pada tanggal 14 Mei 2019 di kelas Jilid dengan Ustadz Syamsuddin sebagai gurunya. 
Nurkancana menyatakan bahwa evaluasi dilakukan berkenaan dengan proses kegiatan untuk menentukan nilai sesuatu. Sementara, Raka Joni mengartikan evaluasi sebagai suatu proses mempertimbangkan sesuatu barang atau gejala dengan pertimbangan pada patokan-patokan tertentu. ${ }^{28}$ Dengan demikian, antara evaluasi, assessment dan measurement memiliki keterkaitan yang tidak dapat dipisahkan. ${ }^{29}$

Di samping itu, tes tertulis juga dapat digunakan untuk menganalisis dan menyintesiskan informasi tentang siswa. Bentuk kedua suatu evaluasi adalah alat non tes. Alat ini digunakan untuk mengevaluasi penampilan dan aspek-aspek belajar efektif dari siswa. Ketepatan alat non tes perlu diperhatikan oleh para guru, karena sering kali dalam penggunaannya memerlukan pertimbangan subjektivitas yang dapat menghasilkan penilaian yang mungkin bervariasi di antara dua orang guru. Alat non tes kadang ada yang menggunakan pengukuran, tetapi ada pula yang tidak menggunakan pengukuran, sebagai contoh observasi, bentuk laporan, teknik audio visual, dan teknik sosiometri. ${ }^{30}$

\section{Implikasi Metode Al-Miftah Lil ‘Ulum}

Berdasarkan observasi dan wawancara penulis, diantara implikasiimplikasi metode Al-Miftah Lil 'Ulum adalah sebagai berikut:

28 Eveline Siregar dan Hartini Nara, Teori Belajar dan Pembelajaran, (Bogor: Ghalia Indonesia, 2010), h 142.

29 Wina Sanjaya, Perencanaan dan Desain Sistem... h.,242
1) Suasana belajar yang dinamis

Semangat dari santri-santri itu muncul baik ketika pembelajaran berlangsung maupun ketika di luar jam pelajaran, karena walaupun di luar pelajaran mereka terus belajar dengan mengahafalkan nyanyian-nyanyiannya, dan terlihat senang dan menikmati proses belajar seperti itu.

Metode apapun yang akan digunakan hendaknya dapat membawa suasana interaksi atau pembelajaran yang edukatif, menempatkan peserta didik dalam keterlibatan aktif belajar maupun menumbuhkan dan mengembangkan minat belajar serta membangkitkan semangat belajar dan menghidupkan proses pembelajaran yang sedang berlangsung. ${ }^{31}$

2) Lembaga yang mulai redup menjadi lebih dinamis

Ruh visi misi Al-Miftah sendiri yaitu mengembalikan gairah membaca kitab, menghidupkan kembali musholamushola yang sempat redup, yang dulu biasanya sore hari dan setelah subuh ada pengajian, kita ingin kembalikan hidup, pondok pesantren salaf yang mulai tidak percaya diri dengan kesalafannya, kiranya mulai gairah kembali.

Banyak fakta mengenai lembagalembaga yang bergairah kembali setelah mengadopsi metode Al-Miftah. Tentu implikasi ini dirasakan olehlembagalembaga yang sebelumnya mengalami

${ }^{30}$ H.M Sukardi, Evaluasi Pendidikan Prinsip dan Operasional (Jakarta: Bumi Askara, 2008), 11.

31 Syaiful Bahri Djamarah dan Aswan Zain, Strategi Belajar Mengajar, (Jakarta: PT. Rineka Cipta, 2002), h. 85-93. 
kemunduran di bidang pendidikan membaca kitabkuning.

3) Menjadi daya pikat peserta didik

Al-Miftah Lil ‘Ulum ini benar-benar menjadi nilai jual bagi Sidogiri. Hal ini dibuktikan dengan melonjaknya jumlah santri dari berbagai daerah yang mana mereka tidak kenal dengan Sidogiri, akan tetapi kenal dengan metodenya AlMiftah Lil ‘Ulum.

Sebelum hadirnya Al-Miftah Lil 'Ulum, di Sigogiri santri baru itu paling memuncak 1000 santri. Akan tetapi dengan hadirnya Al-Miftah Lil 'Ulum kini di tahun 2019 santri baru mencapai 2000 santri. Dan mereka berasal dari berbagai wilayah di Indonesia, bahkan sekitar 39 orang dari luar negri.

4) Tumbuhnya gairah membaca kitab

Fakta yang terjadi di Sidogiri, sebelum hadir Al-Miftah Lil 'Ulum, di luar kegiatan belajar di kelas, sering dijumpai para santri yang berkumpul ngobrol-ngobrol (jagongan-jawa). Akan tetapi dengan hadirnya ini, suasana mulai berubah menjadi suasana yang gemar membaca kitab. Sering dijumpai para santri yang diskusi membentuk kelompok kecil yang topik pembahasannya masalah-masalah baca kitab dan topik pemahaman redaksi kitab-kitab.

5) Belajar Nahwu yang tingkatannya lebih tinggi menjadi mudah

Belajar baca kitab dengan Al-Miftah

Lil 'Ulum merupakan perantara memahami Nahwu Sorf yang tingkatannya lebih tinggi. Hal tersebut dikarenakan di metode Al Miftah tidak membuat istilah baru, sehingga ketika peserta didik masuk kepada kitab-kitab selanjutnya yang lebih tinggi mereka langsung familiar, terkadang ada metode yang membuat istilah baru, sehingga ketika peserta didik masuk ke tingkatyang lebih tinggi harus adaptasi lagi.

6) Belajar fan (cabang ilmu) selain nahwu menjadi lebih mudah

Dalam memahami cabang-cabang Ilmu Fiqh, Hadits, Mantiq, Balaghoh dan lain-lain, Al-Miftah Lil 'Ulum yang berorientasi di Nahwu dan Sorf ini sangat membantu dalam membaca kitab-kitab cabang-cabang ilmu tersebut agar sesuai dengan kaidah-kaidah yang tepat, sehingga dengan membaca yang tapat ini dapat memunculkan konklusi yang tapat pula.

7) Prestasi baca kitab meningkat

Berdasarkan wawancara penulis, koordinator Al-Miftah Lil 'Ulum yakni ustad Qusyairi Isma'il merima laporan dari pengguna metode Al-Miftah Lil ‘Ulum di luar Jawa (Sulawesi, Aceh, Kalimantan, Batam) bahwa prestasi di bidang baca kitab telah mereka raih dalam berbagai ivent.

Selain itu, pada ivent baca kitab yang diselenggarakan oleh Partai Kebangkitan Bangsa (PKB) tingkat nasional juga santri Sidogiri alumni AlMiftah Lil 'Ulum juga mendapatkan juara. Tak kalah menariknya, beberapa tahun yang lalu ada lomba tingkat Aliyah se-Jawa Timur yang diselenggarakan di Jombang, delegasi dari Sidogiri adalah santri i'dadiyah yang masih belajar Al- 
Miftah Lil ‘Ulum, dan mampu bersaing sehingga mendapat juara 3.

8) Memberi energi rasa percaya diri

Rasa percaya diri ini muncul karena mereka merasa sudah pernah belajar, merasa bisa dan ingin mengajarkannya kepada orang lain, sementara masyarakat kebanyakan haus akan metode seperti itu seningga rasa percaya diri muncul. Hal ini dibuktikan oleh para santri Sidogiri di bulan Ramadhan, banyak diantara mereka yang meminta izin untuk mengajarkan Al-Miftah Lil 'Ulum di daerahnya masing-masing.

\section{Kesimpulan}

Berdasarkan paparan dan analisis data, penulis dapat memberikan kesimpulan sebagai berikut:

1. Perencanaan penyusunan metode dilatarbelakangi keresahan-keresahan yang terjadi di Pesantren Sidogiri diantaranya hasil evaluasi baca kitab yang tidak mencapai target dan Pesantren Sidogiri yang notabenenya lembaga pendidikan tapi lebih dikenal ekonominya dari pada pendidikannya. Dalam penyusunannya, langkah-langkah yang dilakukan meliputi: menentukan tujuan, materi, metode, placement test, alokasi waktu dan media pembelajaran.

2. Metode Al-Miftah Lil 'Ulum di Pesantren Sidogiri di organisir dengan baik, baik di secara internal maupun eksternal. Hal tersebut, dibuktikan dengan pelatihanpelatihan rutin yang diselenggarakan oleh pengurus Al-Miftah baik pelatihan pelajar maupun pengajar.

\section{Daftar Pustaka}

Aly, Abdullah, Pendidikan Islam Multikultural di Pesantren, Yogyakarta, Pustaka Pelajar, 2011

Azizi, Qodzi. Pendidikan Agama Islam Membangun Etika Sosial, Semarang:Aneka Ilmu, 2003

Bawani, Imam, Tradisionalisme Dalam Pendidikan Islam, Surabaya: AlIkhlas, 1993

Bruinessen, Martin van, Kitab Kuning Pesantren dan Tarekat Yogyakarta : Gading publishing, 2015

Dahlan, Abdul Aziz (et.al), Ensiklopedi Islam. (Cet. ke-8. Jakarta: Ictiar Baru Van

Hoeve, 1996

Dalman, Keterampilan Membaca Jakarta:Rajawali, 2014

Djamarah, Syaiful Bahri dan Zain, Aswan, Strategi Belajar Mengajar, Jakarta: PT. Rineka Cipta, 2002

Eveline Siregar dan Hartini Nara, Teori Belajar dan Pembelajaran, (Bogor: Ghalia Indonesia, 2010

Hakim, Taufiqul, Amtsilati: Metode Praktis Mendalami Al-Qur'an dan Membaca Kitab Kuning, Jepara: Al-Falah, 2003

Hamid, Abdul, Mengukur Kemampuan Bahasa Arab Untuk Studi Islam Malang; UIN Malik Pers, 2013

Hamim, Muhammad, Fathul Qorib paling lengkap, Kediri, Santri Salaf Press. Juz 1 
Implementasi Metode Al Miftah Lil Ulum Dalam Membaca Kitab Fathul Qorib Bagi Pemula Di Pondok Pesantren Sidogiri Salafi Kabupaten Pasuruan

Oleh: Maulana Restu \& Siti Wahyuni

Hermawan, Acep, Metodologi Pembelajaran Bahasa Arab, Bandung; Remaja Rosdakarya, 2011

Husna, M. Ahsanul. "Metode Diskusi Dalam Pemebelajaran Kitab Kuning Klasik Dalam Peningkatan Keterampilan Membaca", Universitas Wahid Hasyim, 22019

JJ. Hasibuan dan Moedjiono, Proses Belajar Mengajar, Bandung: PT. Remaja Rosdakarya, 1995

Kunndar, Penilaian Autentik, Jakarta: PT Raja Grafindo Persada, 2013

Masykuri, Syaifuddin, Kajian dan Analisis Alfiyyah, Kediri: Santri Salaf Press, 2016

Mochtar, Affandi, Kitab Kuning dan Tradisi Akademik Pesantren Bekasi; Pustaka Isfahan, 2010

Mochtar, M. Masyhuri, Dinamika Kajian Kitab Kuning di Pesantren, Pasuruan: Pustaka Sidogiri, $1436 \mathrm{H}$

Moeloeng, Lexy J. Metodologi Penelitian Kualitatif edisi revisi, Bandung: PT. Remaja Rosdakarya, 2012

Qomar, Mujamil, Manajemen Pendidikan Islam, Jakarta: Penerbit Erlangga, 2007

Ramayulis, Metodologi Pendidikan Agama Islam, Jakarta: Kalam Mulia, 2010

Sanjaya, Wina. Perencanaan dan Desain Sistem Pembelajaran, Jakarta: Kencana Prenada Media Group, 2012
Santoso, Gempur, Fundamental Metodologi Penelitian Kuantitatif dan Kualitatif, Jakarta: Prestasi Pustaka, 2005

Sudjana, Nana. Dasar-Dasar Proses Belajar Mengajar, Bandung: Sinar Baru Algensindo, 2009

Sukardi, H.M Evaluasi Pendidikan Prinsip dan Operasional Jakarta: Bumi Askara, 2008

Syarif, "Tradisi Dan Kontektualisasi Kitab Kuning di Pesantren: Studi Kasus di Pondok Pesantren Miftahul Huda Manonjaya Tasikmalaya", Balaia Penelitian Agamaa Jakartaa 2014

Syukur, Fattah, Metodik Khusus Pendidikan Agama Islam, Semarang : AKFI Media, 2009

Tarigan, Henry Guntur, Membaca Sebagai Suatu Keterampilan Berbahasa Bandung: Angkasa, 2008

Usman, Uzer, Menjadi Guru Profesional, Bandung: Remaja Rosada Karya, 2009 